INTERNATIONAL JOURNAL OF RESEARCHES IN BIOSCIENCES, AGRICULTURE AND TECHNOLOGY (C) VISHWASHANTI MULTIPURPOSE SOCIETY (Global Peace Multipurpose Society) R. No. MH-659/13(N) www.vmsindia.org

\title{
EFFICACY OF DIFFERENT SEED DRESSING CHEMICALS ON SEED MYCOFLORA, SEED GERMINATION AND SEEDLING VIGOUR OF SOYBEAN (GLYCINE MAX L.)
}

\author{
S. Charjan ${ }^{1}$, R. Deotale ${ }^{2}$, P. Lambat ${ }^{3}$, R. Gadewar ${ }^{3}$, \\ A. Lambat ${ }^{3}$ and $M$ Patil $^{3}$ \\ 1College of Agriculture, Nagpur \\ ${ }^{2}$ Mathuradas Mohata College , Nagpur \\ ${ }^{3}$ Sevadal Mahila Mahavidyalaya and Research Academy, Nagpur
}

\begin{abstract}
The Three different fungicides, Captan, Catafol and Dithane M-45 were used to test their efficacy in controlling the seed mycoflora of Soybean. Among them Captan and Captafol were highly effective on seed mycoflora. Dithane M-45 failed to control seed mycoflora at the lower dosage and showed phytotoxic effect on seedling at higher dosage. In contrast, Captan and Captafol did not show any adverse effect on seed germination.
\end{abstract}

\section{Introduction :}

Seed treatment is the cheapest and often the safest method of plant disease control. The seed treatment with fungicides is essential because when the seed germinates, a large number of pathogen carried with the seed become active and cause either seed or seedling mortality or produce diseases at later stages. The purpose of seed treatments by the use of fungicides is to destroy of seed borne fungi that cause seedling blight, seed decay or other diseases. Such treatments also protect the germinating seed from the attack of certain soil inhabiting fungi.

In the present investigation three different seed dressing chemicals were used in soybean to improve seed germination and seedling vigour by overcoming the problem of seed- borne fungi.

\section{Materials and Methods :}

The three different seed dressing chemicals, Captan, Captafol and Ditane M-45 were dusted separetly on Soybean seeds of variety JS-335 at three different concentrations of $0.2,0.25$ and 0.3 percent. 200 seeds of such treatment for each fungicide were evaluated for seed mycoflora using standard blotter method. On the other hand, 100 seeds of each chemical treatment were rolled in paper towels and kept for germination. On the $8^{\text {th }}$ day of incubation under standard conditions of temperature and humidity the paper towels were unrolled and the percentage of seed germination, root- shoot length and seedling vigour were calculated. In these cases the untreated seeds served as control.

\section{Result and Discussion}

The effect of fungicidal seed treatment on seed mycoflora (Table1) revealed that captan suppressed the seed mycoflora at $0.3 \%$ concentration except Alternaria alternate, Macrophomina phaseolina, Curvularia lunata, Rhizopus sp., Phoma sp., and captafol controlled some seed mycoflora at higher concentration but was less effective on Alternaria Alternata, Macrophomina phaseolina, Aspergillus niger, Rhizopus sp., and Phoma sp. Dithane M-45 did not control seed mycoflora even at higher concentration.

Captan and Catafol were highly effective in controlling the several field fungi as well as strorage fungi. As a result Alternaria zinnia, Actinomycete sp., Drechslera halodes, D. hawaiiensis, Cladosporium cladosporioides, Aspergillus flavipes and A. nidulans were failed to express on the treated seeds compared to their existence in Dithane M-45 treatment. The lower concentration of $0.2 \%$ was sufficient to inhibit their colonization on the seeds (Table 1).

The funicidal effect depends on several factors like seed moisture, chemical background of the seed, seed texture, seed size, dosage, duration and method of treatment.

Captan mainly acts as a protectant, but in some cases it is claimed to have acted systemically. The effectivity of the fungicide Captan in suppressing the colonization of fungi is most probably due to the inhibition of the endogenous respiration of the fungal spores. This was claimed by Owens and Novotny (1) in case of the fungus Neurospora sitophila. Captan was also used to treat the Collectotrichum infected seeds and its efficacy on fungal infection was discussed by Lokesh and Shetty (2).

Captafol is available under different names such as Difolatan, difosan, Sanspor, etc. Although it $\mathrm{s}$ mainly recommended for foliar sprays, it has been used for seed dressing, as well as soil applications (3) dithane M-45 is also 
called as Manoczeb or Maneb as such is not marketed in India, but is available in mixture with other chemicals. Though, Maneb has been successfully used against a wide variety of diseases, particularly of vegetables, in the present study it failed to a greater extent in controlling many fungal species. At the same time it was phytotoxic and thus reduced the seed germination and seedling vigour (Table 2). This observation is in confirmation with Kuiper (4) who reported, decreased germination in wheat due to Maneb. Non toxicity of Maneb to seed mycoflora is most probably due to the loss of fungicidal property of the chemical under the conditions of incubation.

Captan and Captafol showed no adverse effect on seed germination and seedling vigour. The increased concentration of Dithane M-45 showed slight adverse effect on seed germination. In association with Rhizopus sp. it induced the symptoms like root-rot and browning. Seeling vigour was reduced in Dithane M-45 chemical treatment (Table 2). Thus, the observations indicated the reliability of the fungicide Captan and Captafol as a promising aid of the seed treatment in Soybean.

Table. 1. Effect of some common seed dressing chemicals on percent incidence of seed mycoflora of Soybean variety JS-335.

\begin{tabular}{|l|l|l|l|l|l|l|l|l|l|l|l|}
\hline \multirow{2}{*}{ Fungi } & \multicolumn{7}{|c|}{ Concentration of Fungicides $\%$ ) } \\
\cline { 2 - 13 } & \multirow{2}{*}{ Control } & \multicolumn{2}{|c|}{ Dithane M-45 } & \multicolumn{3}{c|}{ Captan } & \multicolumn{3}{c|}{ Captafol } \\
\cline { 2 - 12 } & 0.2 & 0.25 & 0.3 & 0.2 & 0.25 & 0.3 & 0.2 & 0.25 & 0.3 \\
\hline Actinomycet sp. & 30 & 23 & 20 & 20 & - & - & - & - & - & \\
\hline Alternaria alternate & 35 & 10 & 10 & 8 & 6 & 6 & 4 & 7 & 4 & 5 \\
\hline A. zinnia & 1 & 1 & 1 & 1 & - & - & - & - & - & - \\
\hline Aspergillus flavipes & 2 & 2 & 2 & 2 & - & - & - & - & - & - \\
\hline A. flavus-oryzae & 30 & 13 & 10 & 08 & - & - & - & 1 & - & - \\
\hline A. Flavus & 52 & 35 & 21 & 17 & 2 & - & - & - & - & - \\
\hline A. nidulans & 2 & 2 & 1 & - & - & - & - & - & - & - \\
\hline A. niger & 40 & 29 & 22 & 16 & - & 1 & - & 2 & 1 & 1 \\
\hline A. ochraceus & 13 & 4 & 5 & 8 & - & - & - & - & - & 1 \\
\hline A. versicolor & 20 & 45 & 35 & 20 & - & 1 & - & 1 & 1 & - \\
\hline $\begin{array}{l}\text { Cladosporium } \\
\text { cladosporioides }\end{array}$ & 10 & 10 & 06 & 04 & - & - & - & - & - & - \\
\hline Curvularia lunata & 2 & 2 & 2 & 1 & - & - & 1 & 1 & - & - \\
\hline Drechslera halodes & 2 & - & - & 1 & - & - & - & - & - & - \\
\hline D. hawaiiensis & 2 & 1 & 2 & 2 & - & - & - & - & - & - \\
\hline $\begin{array}{l}\text { Fusarium } \\
\text { moniliforme }\end{array}$ & 10 & 2 & 1 & 1 & 1 & 1 & - & - & - & - \\
\hline F. solani & 2 & 2 & 1 & - & 1 & - & - & - & - & - \\
\hline $\begin{array}{l}\text { Macrophomina } \\
\text { phaseolina }\end{array}$ & 10 & 10 & 6 & 4 & 1 & 4 & 3 & 4 & 4 & 3 \\
\hline Memnoniella sp. & 2 & 2 & 4 & 4 & - & - & - & - & - & - \\
\hline Mucor sp. & 15 & 21 & 16 & 10 & 2 & - & - & 2 & 2 & 3 \\
\hline Penicillium sp. & 10 & 10 & 08 & 4 & - & - & - & - & - & - \\
\hline Phoma sp. & 4 & 4 & 3 & 1 & 1 & 1 & 1 & 5 & 3 & 2 \\
\hline Rhizoppus sp. & 20 & 4 & 05 & 05 & 2 & 1 & 4 & 3 & 2 & 3 \\
\hline
\end{tabular}

Table 2. Effect of fungicides on seed germination and seedling vigour of Soybean variety JS-335.

\begin{tabular}{|l|l|l|l|l|l|}
\hline Fungicide & $\begin{array}{l}\text { Concentration } \\
(\%)\end{array}$ & $\begin{array}{l}\text { Seed } \\
\text { germin-ation }(\%)\end{array}$ & $\begin{array}{l}\text { Shoot } \\
\text { length }(\mathrm{cm})\end{array}$ & $\begin{array}{l}\text { Root } \\
\text { length }(\mathrm{cm})\end{array}$ & $\begin{array}{l}\text { Vigour } \\
\text { index }\end{array}$ \\
\hline \multirow{3}{*}{ Captan } & 0.2 & 88 & 7.81 & 7.00 & 1303.28 \\
\cline { 2 - 6 } & 0.25 & 89 & 7.92 & 7.14 & 1340.34 \\
\cline { 2 - 6 } & 0.3 & 92 & 7.90 & 7.20 & 1389.20 \\
\hline \multirow{3}{*}{ Captafol } & 0.2 & 88 & 7.72 & 7.01 & 1296.24 \\
\cline { 2 - 6 } & 0.25 & 88 & 7.81 & 7.14 & 1315.60 \\
\cline { 2 - 6 } & 0.3 & 90 & 7.94 & 7.21 & 1363.50 \\
\hline \multirow{3}{*}{$\begin{array}{l}\text { Dithane } \\
\text { M-45 }\end{array}$} & 0.2 & 88 & 7.94 & 6.51 & 1218.80 \\
\cline { 2 - 6 } Control & 0.25 & 85 & 6.12 & 6.14 & 1042.10 \\
\cline { 2 - 6 } & 0.3 & 81 & 6.21 & 5.94 & 984.15 \\
\hline
\end{tabular}




\section{References:}

1. OWENS, R.G. \& H.S. NOVOTNY (1959). Mechanism of action of the fungicide Captan (N-trichloro methyl thio-4-cyclohexame-1, 2-dicarboximide). Contribs, Boyce Thompson Trust, 20:171-190.

2. LOKESH, S. \& H.S. SHETTY (1991). In vitro screeing of chilli (Capsicum annuum) seed samples for Colletrotrichum demantium and its control. Indian J. Agric. Sci., 60: 489490.

3. BERGER, R.D. \& A. WOLF (1974). Control of seed-borne and soil-borne mycoses ofFlorida Sweet corn by seed treatment. Plant Dis. Rep., 58 : 922923.

4. KUIPER, J. (1974). Suppression of wheat seedling establishment by maneb. Aust. J. Exptl. Agric. Ani. Husb., 14 : 391-393. 